\title{
Management of Local Own-Source Revenue in Belu Government: A Phenomenological Study
}

AFFILIATION:

1,2,3 Faculty of Economics and Business, Universitas Brawijaya, Indonesia

\section{*CORRESPONDENCE: \\ filemonmarselinustaek@gmail.com}

THIS ARTICLE IS AVAILABLE IN:

https://ojs.unud.ac.id/index.php/jiab

DOI:

10.24843/JIAB.2020.v15.i02.p03

\section{CITATION:}

Taek, F. M., Djhamhuri, A., \& Baridwan, Z. (2020). Management of Local Own-Source Revenue in Belu Government: A Phenomenological Study. Jurnal IImiah Akuntansi dan Bisnis, 15(2), 172-186.

\section{ARTICLE HISTORY}

Received:

04 March 2020

Revised:

12 April 2020

Accepted:

02 June 2020

\author{
Filemon Marselinus Taek ${ }^{1 *}$, Ali Djhamhuri², Zaki Baridwan ${ }^{3}$
}

\begin{abstract}
This study aims to explore the management of local own-source revenue in the Belu District government with a phenomenological approach, namely an awareness study of the experience of the State Civil Apparatus in managing local own-source revenue and to explain the meaning of the actions taken. The researcher uses the interpretive paradigm understanding method to uncover the aims and objectives of the informants and uses the Husserl phenomenology approach to explain or uncover the phenomenon of experience based on awareness that occurs by individuals, which in this case is the State Civil Apparatus which directly manages local own-source revenue. The results of the study revealed that the informants interpreted the management of local ownsource revenue as duties and responsibilities related to the management of Regional Original Revenues including the management of regional taxes whose revenue always fluctuates due to non-compliance of taxpayers. Management of the results of the separated regional wealth always exceeds the target by means of equity participation in BUMD, management of other original authentic regional income by depositing regional cash to the bank and finding other sources of revenue through the auction of assets in the form of vehicles. The management of retribution is constrained due to various obstacles including the lack of adequate facilities.
\end{abstract}

Keywords: Public sector accounting, local own-source revenue, phenomenology, interpretive paradigm, local tax.

\section{Introduction}

Issuance of Law No. 23 of 2014 concerning local government as a revision of the LAW No. 32 year 2004 becomes the correct time to change policy direction regarding the implementation of decentralization and regional autonomy. Decentralization is one of central government policy where several affairs by the central government is given to autonomous regions based on autonomous principles. This means the area is empowered to determine the various policies based on the autonomy principle. 
Bahl and Linn (1992) suggest that by being handed over some authority to the local government, it is hoped that the service to the community is increasingly efficient and will ultimately promote the economic growth and welfare of the local community (Zulyanto, 2010).

Through decentralization, financial relations occur between the central government and local governments. This indicates that it takes a certain system to dispenses financial authority between the center and the districts. It is intended that in addition to the central government has its income sources, through fiscal decentralization policy areas are also expected to have the certainty to obtain acceptance from sources derived from the potential of the area, so it depends not only on the financial sources of the central government. Nurhemi (2015) states that fiscal policy is generally stipulated in income and expenses consisting of three main activities related to, government policy related to the purchase of goods and services, taxation policy; and payment of policy transfers (e.g., social security allowance, welfare payments) for households. From the three policies above the taxation policy is very influential to the local own-source revenue (PAD) because it relates to local government policies in order to collect local taxes.

Regional autonomy aims to accelerate economic growth and regional development, reduce community gaps and improve the quality of public services to be more efficient and dependencies to the needs, potentials and characteristics and needs of people in the region (Syukri \& Hinaya, 2019). In implementing autonomy, the central government provides to the areas of various sources of financing in order to support the implementation of autonomy including the local own-source revenue (PAD) as the main source of financing and is expected to be able to finance all the financing of regional autonomy. Andriani \& Wahid (2018) said that the implementation of regional autonomy that focuses on district/city areas is characterized by the submission of a number of authorities to determine the allocation of resources owned for regional expenditure by adhering to the principles of compliance, needs, and the regional capabilities listed in the regional budget. Rani et al. (2010) suggests that the local own-source revenue (PAD) is an important indicator to assess the success of regional autonomy because the contribution of PAD in the APBD is a measure of success in the implementation of development, improvement of service, and improvement of public welfare. PAD enhancement will encourage regional economic growth.

Data based on the appendix of the Ministry of Interior Affairs of the Republic of Indonesia No. 38 year 2018 about the guidelines for drafting the budget of regional income and expenditure year 2019 revealed that local governments should make efforts to increase regional income from local tax and local levy considering regional tax increase trends and regional retribution for 5 years starting from the fiscal year 20142018 nationally increased on average of $\mathrm{Rp} 12.38$ with descriptions for the average provincial government increased by $\mathrm{Rp} 6.40$ trillion or $5.84 \%$ and for the average district/city government increased by RP5, 98 trillion or $12.01 \%$. The trend of regional tax proportions and regional retribution on the total indigenous revenue of the region for 5 years starting from the fiscal year $2014-2018$ nationally on average of $76.37 \%$, with a description for the provincial government averaging at $87.17 \%$ and for the district/city government on average of $59.76 \%$.

Based on the data above, this is also the case with the government of Belu regency where the data on the realization of original revenue of the district government 
of Belu in the year 2016-2018 fluctuates with revenues of Rp 74,823,080,565 year 2016, Rp 101,246,072,215 year 2017 and year 2018 of Rp 88,592,824,575. This gives an idea that there is an increase in revenue that directly proves that the management of the regional financial resources is getting better even though the number is relatively small, but with the presence of regional acceptance from the PAD then it will contribute to the development of the area.

Based on the above, it is necessary to use a research approach in understanding the management of regional finances relating to local income. Researchers chose to use the phenomenological approach to exploring the management of the local own-source revenue (PAD) in the Belu district government. This relates to the increase of regional independence, the local government must adapt and strive to improve the quality of public services and improvement in a variety of sectors that have the potential to be developed into a source PAD. The purpose of this research is to understand the management of local own-source revenue (PAD) in the district government Belu based on the experience from civil apparatus of the state as well as to understand and reveal the social significance. The results of this research can contribute to the development of local government policies in order to improve the welfare of the community where not only focus on the materiality but also on the social side. This research can also prove that with the management of good regional financial resources can provide a fluctuations of acceptance of local own-source revenue (PAD) sourced from local taxes, regional retribution, the wealth of state-separated results, and other legitimate PAD.

Researchers briefly explain the realm of accounting research in qualitative research so that readers understand the intent of the study. It is related in the context of accounting sciences, in the case of epistemology debate that occurs, cannot be separated from the point of view in understanding the phenomenon that occurs in the field of discipline. As a system of knowledge, accounting is a system of knowledge that regulates public interaction in presenting financial information that can then be used as a decision making process. This understanding makes accounting function as a system of knowledge that is beneficial to interpret and give meaning to a condition, as reflected in the actions of organizations and individuals in its operational activities (Atmadja, 2013). Djamhuri (2011) suggests that any research included in accounting research has its own philosophical assumptions as it is important to judge appropriately the philosophical assumptions as well as the theoretical basis that lubricated each type of scientific research to make the philosophical as well as theoretical basis used in the study consistent or reflect the scholarly beliefs/paradigms used by researchers.

Johnson (1992) argues that when accounting as a system of knowledge, then it can be said that accounting as one of the social realities because individuals are forced, guided, assured, encouraged, or in some way influenced by the various social realities in his/her social environment and thus, social reality is born in the form of a way of acting, thinking, and feeling that demonstrates the nature worth seeing as something that is beyond individual consciousness (Atmadja, 2013). If associated with the organization, the organization is also a study of sociology so that reviewing accounting problems using a sociological approach has a strategic meaning which can be attributed to the accounting aspects from micro to macro level (Covaleski \& Aiken, 1986).

If accounting as a social reality, then with a variety of knowledge generated by individuals, used for such individuals in their social environment, then accounting is no different. Tinker (1975); Lowe, E.A \& Tinker (1977) said that like other empirical-based 
discourse, accounting seeks to reestablish the relationships between people, their needs, and their environment and in the relationship of feedback, accounting thinking itself changes when humans, their environment, and their perception of their changing needs (Chua, 1986). With the interactive relationship between knowledge and man, the production of knowledge is limited by the rules or man-made beliefs. Furthermore, Djamhuri (2011) suggests that in general the other matter in accounting, humans only focus on conventional views where it centers on one true view without any other alternatives. This is precisely placing in a difficult position because it does not know the mistakes that may occur.

Local own-source revenue (PAD) is a regional income derived from local tax results, regional retribution results, the results of the regional wealth management separated, and other original legitimate income, which aims to provide flexibility to the area in digging funding in the implementation of regional autonomy as a foundation of decentralized principles. Local own-source revenue is the income gained by the area imposed based on local regulations (Law No. 33 year 2004 on financial balance between the central and local governments).

PAD is estimated to weigh the performance or the actual achievement of PAD previous years and consider the condition of natural environment, social culture, change the potential development of income source and do not burden the local people and the business world. Additionally, a gradual increase in budget PAD illustrates the performance improvement of local governments.

Broadly speaking, the regional original revenue consists of local tax which is a mandatory contribution to the area owed by a private person or a forced body based on law with no direct remuneration and use for regional purposes for the maximum prosperity of people (Act No. 28 year 2009 on local tax and regional retribution). Regional taxes are differentiated into two namely provincial tax and district/city tax. Regional retribution is the regional levy as payment for certain services or permits that are specifically provided and/or provided by the local Government for the benefit of the individual or agency (Act No. 28 year 2009 on local tax and regional retribution). Kurniawan (2019) said that the regional levy is a regional revenue contributed to the financing of local governments and to increase the acceptance of regional retribution should be established based on local regulations that are guided by the tax laws and local levy. The object of retribution imposed by the provincial and regency/city governments is divided into three namely public service levy, business services levy and certain licensing levies. The result of the wealth management of the separated area is the acceptance of the area derived from the management of the area of segregated property (Halim \& Kusufi, 2014). The type of income includes the return on capital investment in BUMN/BUMD. Other legitimate PAD is a revenue received by local government in the form of the sales of regional assets, interest income.

\section{Research Method}

It is important for a researcher to bring confidence, assumptions, and critical thoughts in research or research that will be conducted in researching a particular phenomenon. Researchers use interpretive paradigm understanding methods to uncover the intentions and objectives of the informant. Burrell \& Morgan (1979) explains that the interpretive paradigm is rooted in the sociology of regulation with a subjective standpoint. The main concern is in how to understand the world as it is, to understand 
the fundamental habits of the social world based on subjective experience. The interpretive paradigm seeks to explain in a person's consciousness world, in the reference frame of the person directly involved, not as an observer.

Researchers use Husserl's phenomenological approach to explain or uncover the phenomenon of experience based on the awareness of the individual, which in this case is the State Civil Apparatus (ASN) that directly manages the PAD. Transcendental Phenomenology was introduced by Edmund Huserl who focuses on a study of consciousness. A study focused more on the concept of "I". According to Huserl, "I" is the center of the entire ward (Umgedude) with an assertion that the existence of "I" distinguishes one human being with another man based on the experience that forms perception, memory, expectation, and different fantasies (Kamayanti, 2017).

The study of phenomenology uses sources who have experience as a subject of research (Creswell, 2015). The subject of research as the primary informant because it has experience and provides the right and useful information to answer research problems based on the experience. The subject to research is the ASN which has experience and role in the organizational structure that directly manages the regional indigenous revenue. Researchers determine where the research is based on regional device organizations (OPD) whose operational activities are directly related to the management of regional indigenous revenue. The informant in this study amounted to 8 (eight) people shown in Table 1. In the data collection activities, researchers do the determination of places or individuals i.e. individuals who experience the phenomenon/experience management of the PAD within the governance of Belu regency. Access and relationship is done by looking for individuals who experience PAD management experience in the government of Belu district that is an individual who works for the office that manages the PAD, then researchers make a research letter addressed to the service and ask for individual approval.

Table 1. List of Information Sources

\begin{tabular}{|c|c|c|}
\hline No & Report & Description \\
\hline 1. & Drs. Marsel Mau Meta & $\begin{array}{l}\text { Head of financial management and regional } \\
\text { assets of Belu Regency }\end{array}$ \\
\hline 2. & Jonisius R. Mali, SH & Head of regional revenue Agency \\
\hline 3. & Silvia Celeste Do Amaral, S.STP & Secretary of the Regional Revenue Board \\
\hline 4. & Yasintha Mutik Loes, SE & $\begin{array}{l}\text { Head of data collection, valuation and } \\
\text { determination regional revenue Agency of } \\
\text { Belu Regency }\end{array}$ \\
\hline 5. & Benediktus Bere, SE & $\begin{array}{l}\text { Head of bookkeeping, regional revenue } \\
\text { reporting of regional revenue Agency of Belu } \\
\text { Regency }\end{array}$ \\
\hline 6. & Rosalia Yeani Er. Lalo, SH & $\begin{array}{l}\text { Head of system and billing and objection } \\
\text { procedures of regional revenue Agency of } \\
\text { Belu Regency }\end{array}$ \\
\hline 7. & Maria Theresia Bere Ati, S.AP & $\begin{array}{l}\text { Head of regional revenue development and } \\
\text { evaluation of regional revenue Agency of } \\
\text { Belu Regency }\end{array}$ \\
\hline 8. & Drs. Mikael Baba & Head of Belu District transportation Office \\
\hline
\end{tabular}

Source: Processed Data, 2019 
The informant determination strategy is done by looking for individuals who experience the experience of managing PAD using snowball sampling (recommendations from subjects to other subjects that can provide information or experience). The data form relates to the data to be collected in the form of interview results with the individual experiencing the experience of managing the PAD. Recording of information is being done through the use of stationery and electronic media in the form of mobile phone to record the interview.

Before the researchers conduct interviews with individuals, researchers have avoided conflict of interest and prejudice, researchers who Husserl called the term Epoche so that questions during the interview process that developed the individual experience and the results of interviews are purely an individual experience (pure consciousness). After the data collection has completed, then continued to data analysis process.

The data sources in this study use primary and secondary data sources. Primary data is specifically gathered by researchers to answer research questions in the form of individual opinions and experiences. Primary data is obtained and collected by researchers through deep interviews with the State Civil Apparatus (ASN) of the Belu District government. Researchers choose the informant by setting specific criteria that are appropriate for the research purpose so that it is expected to answer research problem. Researchers also use secondary data in the process of collecting data in the form of financial statements. In analyzing the data, researchers use the method of data analysis by (Moustakas, 1994). Moustakas (1994) modifies and simplifies data analysis methods from Stevick (1971); Colaizzi (1973) and Keen (1975) methods. The steps are: first, describing the complete events/phenomena directly experienced by the informant. Secondly, studying every verbal statement relating to the research problem, recording and noting the relevant statements, the statements that have been recorded are then listed (Invariant Horizons/unit meaning phenomenon), then classify each unit of meaning into certain themes and create synthesis from units of meaning and theme (description of textural), including verbal revelation that becomes the core unit of meaning. By preserving the reflection of the structural explanation of oneself through the variation of imagination, researchers make a structural description of the construct and then combine the description of textures and structural to determine the meaning and essence of the phenomenon. Third, make a thorough explanation of every meaning and essence of the phenomenon obtained. Creswell (2015) presents a data analysis method from Moustakas (1994) which researchers described in Figure 1.

\section{Result and Discussion}

Related to the management of PAD especially local tax. The informant experience in managing PAD in particular local tax experienced some impressive experiences. Related to the performance of tax revenues Belu regency looks increasingly improved from the acceptance side. This is evidenced by the regional tax realization of Belu Regency is recorded to meet and exceed the target in the last two years. The local tax as the biggest contributor to the Belu district is a major contribution which is non-metallic Mineral tax, Hotel tax, restaurant tax and PBB P2. It is like one of the informant that is Mrs. Silvia:

"Ohh, the most contributing or the "Primadona" is a non-metallic mineral because it contributed the greatest tax, there were projects. " 
Taek, Djhamhuri \& Baridwan

Management of Local Own-Source Revenue in Belu Government: A Phenomenological Study

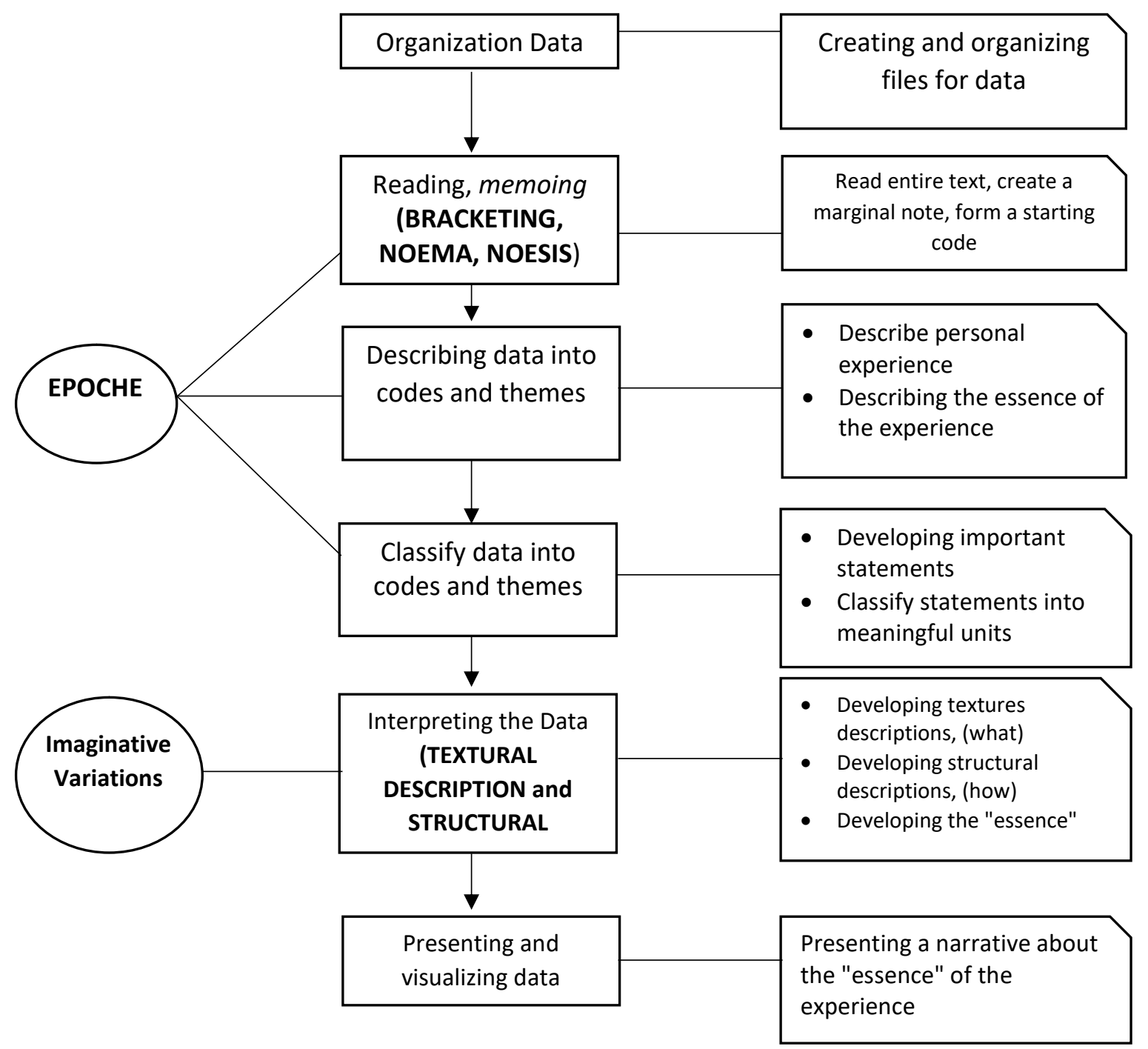

Figure 1. Analysis and Serving Data of Phenomenology

Source: Creswell, 2015; Ardiansyah, 2019

$\begin{array}{ll}\text { Epoche } & : \text { get rid of personal researchers experience } \\ \text { Bracketing } & : \text { Process of confinement phenomenon } \\ \text { Noesis } & \text { : what is experienced } \\ \text { Noema } & \text { : how to experience } \\ \text { Horizonalizing } & \text { : corrects and selects meanings } \\ \text { Cluster of Meaning } & \text { : classify statements into meaning units } \\ \text { Imaginative Variation } & \text { : reflecting thinking } \\ \text { Textural Descriptions } & \text { : describe what experience } \\ \text { Structural Descriptons } & \text { : describing how to experience }\end{array}$

Mrs. Sivia suggested that non-metal and rock mineral taxes became "primadona" or contributed greatly to the reception because the Belu district government was collecting regional taxes from non-metal and stone mineral mining activities that the company did in order to build roads at the border. This is because the 
district Belu is a border area with the neighboring country of Timor Leste and through one of the central government programs, namely to build and connect the streets of the border areas known as the term "red belt".

In organizing PAD in particular local tax, informant experienced a conscious experience of various experiences in relation to local taxpayer disobedience and low level of awareness resulting in an attempt to avoid tax. It is based on the experience of one of the informant, Mrs. Shinta, who said:

"Their level of consciousness is too low while its potential acceptance is great. Continuing, their character is always dodging, avoiding tax." A lot of reason until we did the examination. Well, the examination in the regulation is set up for them to make bookkeeping but this is absolutely nothing, there is absolutely nothing (repeating the word "absolutely nothing" while showing a disillusioned facial expression). No simple bookkeeping exists. They are term like managing their own households. Accept money, shopping, do not want to separate him or her profit at least make a simple bookkeeping does not exist. That's what we think is crucial the problem because if we want to clay it's not because he is lazy or what but because of the character. Because from one go tell to the other "

Another thing that is to increase the acceptance is the effort "uji petik" by lowering the officer to the stalls that have been paid and report the tax incorrectly so that based on the reality found then Regional Revenue Agency (Bapenda) can make a letter of decree. Quotation tests are also used as a means to determine the tax obligations owed so that the taxpayer cannot avoid and dodge again based on the quotation. One of the informant, Mr. Bene, stated that the quotation test was an attempt to suspect any indication of tax fraud. He said that:

"We do the uji petik. We send the officers there to take notes there. There we do a month up to a full month against the Restaurant that we suspect there is an indication of tax fraud, that we deposited the officers there to test the quotation of admission him from morning to evening, it was up to a month even. "

Tax irregularities constitutes an indication of a taxpayer's fraud in its tax obligations. Taxpayers will attempt to exploit the opportunity to pay the minimum tax. Mangoting (2018) suggest that the Government implements voluntary compliance in the taxation system. This voluntary compliance is based on the Self-Assessment tax system. The tax-collection system provides the taxpayer the opportunity to fulfill the tax obligations based on the law and the provisions of the implementation by not relying on an assignment to calculate, pay, and report the tax owed. This is what makes taxpayers will try to capitalize on the opportunity to pay a minimum of taxes, one of which is doing tax fraud. According to Mr. Bene by conducting quotation tests, stalls suspected of committing tax malpractice can be given a deterrent effect with results based on quotation tests. Through the custody of the stall to each taxpayer, it can provide information about its acceptance.

In connection with disobedience and fraud committed by taxpayers, the district Bapenda Belu approaches and socializing as a means to raise taxpayer awareness. Year to year, Bapenda district of Belu as district tax manager has conducted various approaches and socialization so that taxpayers in Belu district to be aware and taxabiding. The informant is aware that socialization is an effort that must be pursued so that people can understand the meaning of its tax obligations. The approach to taxpayers is also done face to face with the intention of establishing a personal 
relationship. On the other hand, also do reward to the government and taxpayers. It is based on the experience of the informant, Mrs. Yeni.

"We give reward, appreciation in the form of charter appreciation to the tax collector officers, village head and the Lurah which is considered to be performing well in the community, they can encourage the public to pay taxes before maturity."

"Face to face to build emotional relationships, coordination, and so on. The term of the market is wooing, persuading... like that, encouraging them. "

Mrs. Yeni realizes that if a socialization certainly gives understanding of taxation knowledge to taxpayers and provides ease. On the other hand, the reward is crucial because for the government, appreciating the tax officer shows an effort to maintain the human resource assets that can create government acceptance in the regional tax sector in the long term whereas for its own taxpayer the feeling appreciated will increase their motivation to obey paying taxes. Therefore, creating tax compliance should be a psychological approach to taxpayers because tax compliance is related to taxpayers. This is in line with Putri \& Nurhasanah (2019) said that a lack of socialization has impacted low public knowledge of taxes that ultimately led to ow public awareness of reporting and paying taxes. In addition to improving taxation compliance, tax socialization also affects taxation knowledge for taxpayers. Tax knowledge is a result of socialization of taxation and also potentially improving taxation compliance.

In relation to local tax management, there was a share of other obstacles in managing the lack of human resources (SDM) that resulted in the management of tax areas was slightly hampered. This is due to the less capable Skill and various educational background and always the mutation of employees so as to adapt to the work carried. This was experienced by Mrs. Yeni, based on her experience, said:

"Its human resources are also still low. Human resources are low (low-pitted). I have staff in human resources that is low, the skills are low, so we need that good mastered if for Regional Revenue Agency (Bapenda). It is also an obstacle. Yes, indeed why still low PAD because of human resources. I think we should evaluate one office because this is a lot of this man (counting)... Civil servants around the 20s, meddling Kettle (contract manpower) We are almost 50-an. But who have a skill, have the HR is a bit. So hard. "

Oluseyi (2010) said that the quality of human resources can be measured from knowledge skills in the sense of increasingly understanding/knowledgeable then the wider human resources insight that is reflected in its competent performance, fast and innovative in learning new regulations (Sudaryati \& Heriningsih, 2014). Furthermore Kuratko, et all (1997) argue that the value of human resources is actually the amount of value of an organization that can be referred to as an intellectual capital consisting of people in the organization, skills they possess, and use them in their work and if this happens in government then if the Government has qualified human resources then it will make the area a prosperous area (Sudaryati \& Heriningsih, 2014).

In managing local tax, the increase in human resources is always done by doing cooperation with various universities and sending the trainees so that through training in the form of trainings not only through the learning process but the practice of conducting comparative studies in real to stalls (related to restaurant taxes). Another thing is for the preparation of human resources in order to carry out the task to achieve the target to match the expected results are important. 
Furthermore, with regard to local tax management, Infoman through her experience gained various resistance from taxpayers. There is a taxpayer's treatment, to the informant and the other tax officer labeled with the phrase "Gayus". A phrase that indicates that the tax officer is always using the tax money from the community. It is as expressed by Mrs. Silvia:

"We often quarrel with the stalls that belong to our brothers who came from Java because they refused to pay. However, I insist that where there is no taxes in Java, there is tax and there is no tax. The law has made her in the center there is not a make in Atambua here. Some are angry and some are saying: "Tax again, tax again" but we accept it. Sometimes there is a throw in money throwing into us but I say "thank you sir, the clear money is not for us but for the area" (laughing with the experience experienced). Their views are ugly. In fact, in their eyes, the tax officer was like "Gayus". My experience and staff have been to the free market and Bill later we called out: " These employees of the Gayus have come ". But inevitably we should take. In Java alone can be much more advanced in Bali. But I always tell the tax officer it's so real money don't get in the personal pocket. "

This experience is a form of treatment by taxpayers directly to tax officers. Silvia's mother realized how to weigh jobs as tax officers. Mrs. Silvia has the realization that her true as a tax officer of all obstacles must be faced in order to later tax revenues can finance the government expenditure for public welfare.

Associated with the management of PAD in particular the property of separated areas and other legitimate PAD. In its management, the informant gives the idea that the realization of PAD is not yet able to finance the expenditure of local government of Belu Regency because of the small PAD, the government dependence of Belu district more to the Balance Fund (DAU and DAK). It is as said by Mr. Marsel:

"We (Regency of Belu) limited area. It means limited financial. We are still fully dependent on DAU and DAK while our PAD contributions to the expenditure are still very-very small but we at PPKAD are burdened to find the original source of income related to our task. "

The Financial and Regional Asset Management Revenue (PPKAD) of Belu Regency as the maintainer of the region's wealth of segregated areas continues to improve acceptance. PPKAD is burdened to find the original source of income related to their duties. The way to do that is to invest in the form of capital inclusion in BUMD Bank NTT. As said by Mr. Marsel:

"The first is capital investment in NTT Bank. The inclusion of this capital later each year in the GMS of the NTT bank, the local government given the name of dividends. The dividend depends on the amount of capital participation that we deposited in the bank. It is very dependent and we have a deposit that is in the NTT bank there are 42 billion more and than 42 billion this, he fluctuates depending on the bank's profit from NTT itself. Last year we gained a dividend of 7.4 billion. "

Dividend is a share of profit to shareholders. Article 304 Act No. 23 of 2014 on local government stating that "the region can engage in capital investments in stateowned enterprises and/or regional owned enterprises (BUMD)". It is one of the efforts that the local government can do to increase the growth of the regional economy and foster a source of regional income by conducting capital investment in BUMD. The inclusion of regional government capital derived from APBD can be carried out as long 
as it does not interfere with regional financial liquidity and local property goods. The consequences of the inclusion of regional government capital conducted in the form of money and local goods is a form of investment of local government by obtaining ownership rights, so that there is a transfer of ownership of money and property of the region that was originally a wealth that is not separated into a wealth separated to be counted as the capital/stock of the area in BUMN, BUMD or other legal entities that.

PPKAD also manages other genuine income legitimate area which is done by means of deposits as an effort to dig further the source of income. By depositing the local cash to the bank, it will benefit from interest. But the information sources realize that it is apparent that the impact of the increasing local government expenditure can affect deposits. In this case the deposit withdrawal can be done before maturity due to cover the mandatory expenditure district government.

"For deposits, usually we are constrained if at the time we already made deposits but our spending that we have to spend it increases, then the deposit was not up to maturity, the money we have to take back because this there are certain mandatory spending that we must do."

The short-term investments conducted by local governments have both advantages and disadvantages. The advantage if the withdrawal at maturity then it will get interest income, but if the withdrawal before maturity then it will be subjected to a penalty that actually resulted in a loss. Belu District government through PPKAD must find solutions to increase PAD not only from short-term investments (deposits) but can also through long-term investments. Ministry of Finance Regulation No. 223/PMK. 05/2016 concerning the statement of Accounting-based standard of the accruals number 06 about investment accounting (revised 2016), giving the idea that long-term investments are divided according to the intention of investing, i.e. permanent and nonpermanent. Permanent investment is a long-term investment that is intended to be owned sustainably (capital inclusion in BUMN or BUMD), while nonpermanent investment is a long-term investment intended to be owned unsustainably (bonds or long-term debt letters, investing in transferable development projects on third parties). In addition to the income in the form of capital participation and savings in deposit, another thing done is the sale of assets through auction. Auction of assets in the form of vehicles that are useless as well as vehicles that cost high exploitation. The asset auction is transparent and addressed to all the general public to avoid fraud. It is done by the informant, Mr. Marsel.

"Then there is another source of income that is managed by us that is the sale of assets. Auction vehicles are the assets that are useless, then the vehicles that cost the high level that we are to be publicly available to add to our PAD "

The sale of local government assets is one way to recognize revenues. But the sale of assets carried out must go through procedures and not arbitrarily. Then he said that "the auction depends on needs". Mr. Marsel's statement reveals that he understands the ordinances and regulations of the law. Government Regulation No. 38 year 2008 on the management of State/ regional goods article 51 paragraph 1 states that the sale of local goods is carried out in consideration: for the optimization of an excess or unused area of the property; economically more profitable for the region when sold; and/or as the implementation of the provisions of legislation. The unused/ used area is an area that is not used for the purpose of organizing the tasks and functions of the SKPD or not utilized by other parties. 
In connection with the management of the PAD is the retribution, researchers conducted research on the District Transportation Office Belu which manages the retribution of the motor vehicle testing (KIR), the retribution of public road parking service, Terminal retribution and Retribution of regional wealth use. The management of retribution is still not optimal due to some obstacles encountered. Reality about the informant's experience of managing retribution, the retribution of the motor vehicle testing (KIR) is a better source of income from the other three retributions. This is because it is related to operation of the vehicle must go through the testing phase, if not, then be imposed speeding ticket. In connection with the management of parking service on the roadside public roads is not optimal because there is no special place for parking and requires the cost of providing a car park.

Terminal Retribution management encountered several obstacles resulting in a stunted winding process. This is felt because of the management of the terminal which is less strategic position as well as related to the facility of the terminal is not adequate, and the path traveled by the vehicle is different from the terminal. It is based on an interview with Mr. Mikael:

"This temporary operation is Naresa. The other two terminals do not operate. Bad. (laughs). These two terminals are Fatubenao with Umanen. The ride in Umanen means that the vehicle will not enter, the terminal is finally quiet. The building that gutters in front of it is higher, making constraints if the car will enter the terminal. So the time when the contractor woke the ditch was delivered but.... (Silent and not continuing the emission).

Then the next one is a vehicle that also does not pass through this terminal but through another line so we want to take how. Fatubenao Terminal from the beginning of Sampe now the building of its terminal is slightly into the area of transportation in front, so the vehicle that travels from the top follow the road only and does not want to stop to the terminal.

Then the road condition is also not good so they objected. So when their operations were forced but they were a lot of protests related to the insufficient available facilitias. So that is the obstacle we face now, we want to force but the community says "We want to find a meal, want to find money" while going to get into the terminal there parking there also who is guard. "

This resulted in the terminal retribution was obstructed and apparently violated the rules because the poll was carried out by means of the road by the Department of Transportation (Dishub) officers against the vehicles passing. This fact researcher gained based on the news published by Timordaily.com on November 4, 2019 with the news headline "Officers from the Department of Transportation (Dishub) Regency Belu, province of NTT RI border-RDTL carry out the collection of withdrawal of terminal retribution in the streets precisely around Daya store, Old Market, Atambua city."

\section{Conclusion}

In organizing PAD in particular local tax, sources experienced a conscious experience of various experiences in relation to local taxpayer disobedience and low level of awareness resulting in an attempt to avoid tax. Taxes are considered as a burden by taxpayers and various excuses are used by taxpayers not to pay taxes. Other thing is to increase the acceptance, then the quotation test which is used as a means to determine the tax obligation that is payable so that the taxpayer cannot avoid and avoid again 
based on the test fact of the quotation. Lastly in managing local taxes, sources through its unconscious experience gets various resistance from taxpayers. There is a taxpayer's treatment, to the informant and the other tax officer labeled with the phrase "Gayus". A phrase that indicates that the tax officer defrauding the tax money.

Second, associated with the management of PAD in particular the property of separated areas and other legitimate PAD in its management, it is the informant to give the idea that the realization of PAD was not able to finance the expenditure of district government Belu because with a small PAD, dependence of the District government Belu more to the Balance Fund (DAU and DAK). Third, PAD management related to the retribution, reality about the informant experience in managing retribution is less understanding the complex of management.

This research has its limitations, the phenomenological characteristics that require the interview process to acquire meaningful understanding to be done face-toface. This research has not achieved this to the fullest extent due to time and information sources availability constraints.

\section{References}

Anantawikrama Tungga Atmadja. (2013). Anantawikrama Tungga Atmadja. Akuntansi Profesi, 3(2), 122-141.

Andriani, R. N. R., \& Wahid, N. N. (2018). Pengaruh Pendapatan Asli Daerah dan Dana Perimbangan Terhadap Kemandirian Keuangan Daerah (Studi Kasus pada Pemerintah Kota Tasikmalaya Tahun 2006-2015). Jurnal Akuntansi, 13(3), 30-39.

Ardiansyah, R. (2019). Amnesti Pajak: Perspective Wajib Pajak Suatu Studi Fenomenologi. Universitas Brawijaya.

Burrell, G., \& Morgan, G. (1979). Assumptions about the Nature of Social Science. In Sociological Paradigms and Organisational Analysis (pp. 1-9). https://doi.org/10.4324/9781315609751-1

Chua, W. F. (1986). Radical Development in Accounting Thaought. The Accounting Review, 61(4), 601-632.

Colaizzi, P. R. (1973). Reflection and research in psychology. IA: Kendall/Hunt.

Covaleski, M., \& Aiken, M. (1986). Accounting and theories of organizations: Some preliminary considerations. Accounting, Organizations and Society, 11(4-5), 297319. https://doi.org/10.1016/0361-3682(86)90002-4

Creswell, J. W. (2015). Penelitian Kualitatif Dan Desain Riset : Memilih Di Antara Lima Pendekatan (Edisi Ke - 3). Pustaka Belajar.

Djamhuri, A. (2011). IImu Pengetahuan Sosial dan Berbagai Paradigma Dalam Kajian Akuntansi. Akuntansi Multiparadigma, 2(1), 1-185.

Faisal A. Rani, M. Syahbandir, Eddy, P. (2010). Kontribusi PAD dalam APBD sebagai Indikator Keberhasilan Otonomi Daerah. KANUN, 8(51), 235-255.

Halim, A., \& Kusufi, M. S. (2014). Akuntansi Sektor Publik : Akuntansi Keuangan Daerah (Edisi 4). Salemba Empat.

Johnson, P. . (1992). Teori Sosiologi Klasik dan Modern (R. M. Z. Lawang (ed.)). PT Gramedia.

Kamayanti, A. (2017). Metodologi Penelitian Kualitatif Akuntansi. Yayasan Rumah Peneleh.

Keen, E. (1975). Doing research phenomenologically. Unpublished manuscript, Bucknell University. 
Kuratko, D. F., Hornsby, J. S. dan Naffziger, D. W. (1997). An Examination of OwnersGoals in Sustaining Entrepreneurship. Journal of Small Business Management, 35(1), 24-33.

Kurniawan, A. (2019). Analisis Pengelolaan Retribusi Daerah Sebagai Strategi Peningkatan Pendapatan Asli Daerah (PAD) (Studi Kasus pada Seluruh Organisasi Perangkat Daerah (OPD) Terkait Retribusi di Kabupaten Tulungagung). Jurnal IImu Administrasi Publik, 5(1), 87-96.

Lowe, E.A \& Tinker, A. . (1977). Sitting the accounting problematic: towards an intellectual emancipation of accounting. Journal of Bussines Finance \& Accounting, 3, 263-276.

Mangoting, Y. (2018). Quo Vadis Kepatuhan Pajak? Akuntansi Multiparadigma, 9(3), 451-470. https://doi.org/10.1515/9783110459418-037

Moustakas, C. (1994). Phenomenological research methods. Phenomenological Research Methods. https://doi.org/10.4135/9781412995658

Nurhemi, G. S. (2015). Dampak Otonomi Keuangan Daerah Terhadap Pertumbuhan Ekonomi Di Indonesia. Buletin Ekonomi Moneter Dan Perbankan, 18(2), 183-206. https://doi.org/10.21098/bemp.v18i2.522

Oluseyi O, A. (2010). A comparative study of the adoption of accrual accounting in government. Cardiff University.

Peraturan Menteri Dalam Negeri Republik Indonesia Nomor 38 Tahun 2018 Tentang Pedoman Penyusunan Anggaran Pendapatan Dan Belanja Daerah Tahun Anggaran 2019.

Peraturan Menteri Keuangan Republik Indonesia Nomor 223/PMK.05/ 2016 Tentang Pernyataan Standar Akuntansi Pemerintahan Berbasis Akrual Nomor 06 Tentang Akuntansi Investasi (Revisi 2016).

Peraturan Pemerintah Nomor 38 Tahun 2008 Tentang Pengelolaan Barang Milik Negara/ Daerah.

Putri, N. E., \& Nurhasanah. (2019). Sosialisasi Pajak, Tingkat Pendidikan dan Sanksi Pajak Terkait dengan Kepatuhan Wajib Pajak UKM (Studi Kasus: Pengusaha UKM Kecamatan Manggar Belitung Timur). Jurnal STEI Ekonomi, 28(02), 213-232.

Stevick, E. L. (1971). An empirical investigation of the experience of anger. Duquesne Studies in Phenomenological Psychology, 1, 132-148. https://doi.org/10.5840/dspp1971114

Sudaryati, D., \& Heriningsih, S. (2014). Pengaruh Kompetensi Sumber Daya Manusia Terhadap Penerapan Akuntansi Akrual Dengan Perangkat Pendukung Sebagai Variabel Moderating (Studi Empiris Pada Pemerintah Kota Yogyakarta). Optimum: Jurnal Ekonomi Dan Pembangunan, 4(2), 181. https://doi.org/10.12928/optimum.v4i2.7795

Syukri, M., \& Hinaya, H. (2019). Pengaruh Pertumbuhan Ekonomi, Pendapatan Asli Daerah, Dana Alokasi Umum Dan Dana Alokasi Khusus Terhadap Anggaran Belanja Modal Kabupaten \& Kota Provinsi Sulawesi Selatan. JEMMA / Journal of Economic, Management and Accounting, 2(2), 30. https://doi.org/10.35914/jemma.v2i2.245

Tinker, A. . (1975). An accounting organization for organizational problem solving. Manchester Bussines Scholl.

Undang-Undang Nomor 23 Tahun 2014 Tentang Pemerintahan Daerah. Undang-Undang Nomor 28 Tahun 2009 Tentang Pajak Daerah Dan Retribusi Daerah. Undang-Undang Nomor 33 Tahun 2004 Tentang Perimbangan Keuangan Antara 
Taek, Djhamhuri \& Baridwan

Management of Local Own-Source Revenue in Belu Government: A Phenomenological Study

Pemerintah Pusat dan Pemerintah Daerah.

Zulyanto, A. (2010). Pengaruh Desentralisasi Fiskal terhadap Pertumbuhan Ekonomi di Provinsi Bengkulu. Jurnal Ekonom, 17(3), 1-122. 